
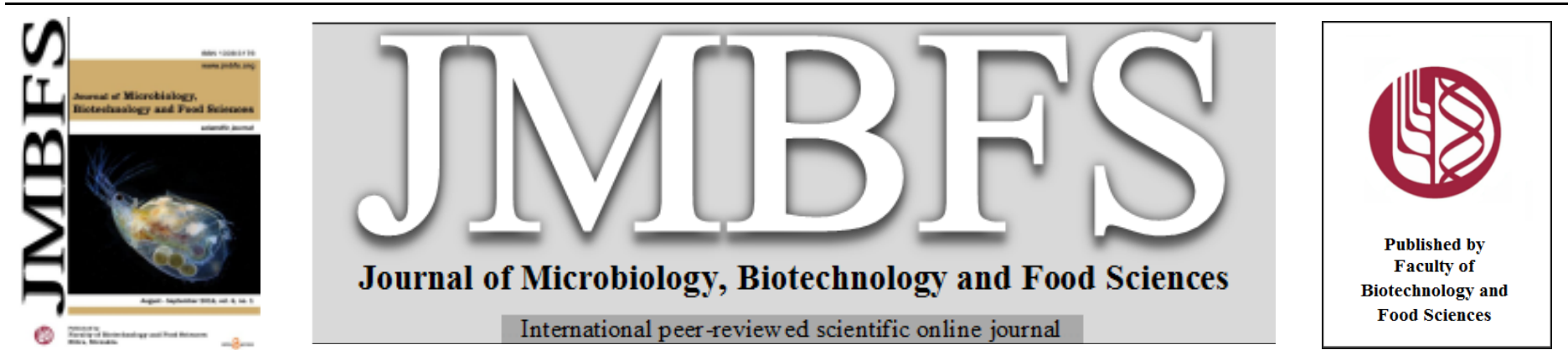

\title{
OPTIMIZATION OF THERMOSTABLE ALPHA-AMYLASE PRODUCTION FROM GEOBACILLUS SP. D413
}

\section{Sennur CALISKAN OZDEMIR ${ }^{1} \cdot$ Arzu COLERI CIHAN ${ }^{2} \cdot$ Tugba KILIC $^{2} \cdot$ Cumhur COKMUS $^{3} *$}

\author{
$\operatorname{Address}(e s):$ \\ ${ }^{1}$ Ege University, Faculty of Science, Department of Biology, Fundamental and Industrial Microbiology Division, 35100, Bornova, Izmir, Turkey. \\ ${ }^{2}$ Ankara University, Faculty of Sciences, Department of Biology, 06100, Tandogan, Ankara, Turkey. \\ ${ }^{3}$ Konya Food \& Agriculture University, Dede Korkut Mahallesi, Beyşehir Cad. No: 9, 42080, Meram, Konya, Turkey.
}

*Corresponding author: ccokmus@gmail.com

doi: 10.15414/jmbfs.2016.6.1.689-694

\section{ARTICLE INFO}

Received 18. 1. 2016

Revised 8. 3. 2016

Accepted 5. 4. 2016

Published 1. 8. 2016

Regular article

OPEN 2 ACCESS

\begin{abstract}
The qualitative and quantitative $\alpha$-amylase production capacities of six thermophilic bacilli were screened. Geobacillus sp. D413 was selected for enzyme optimization, as it displayed higher $\alpha$-amylase activity. The maximum enzyme activities of D413 and $G$. stearothermophilus ATCC $12980^{\mathrm{T}}$ were observed at the time of $72 \mathrm{~h}$. While the optimal $\mathrm{pH}$ of medium for bacterial growth and enzyme production of $\mathrm{D} 413(\mathrm{pH} 7.0)$ differed from ATCC $12980^{\mathrm{T}}\left(\mathrm{pH} 8.0\right.$ ), the optimal temperature for enzyme production was $55^{\circ} \mathrm{C}$ for both. The effects of various carbon and nitrogen sources were determined by changing their concentrations. The highest bacterial growth and enzyme production were sustained by the starch and maltose containing medium. Both bacterial growth and enzyme production were inhibited by $\mathrm{NH}_{4} \mathrm{Cl}$. D413 and ATCC $12980^{\mathrm{T}}$ amylases showed optimal activity at $65^{\circ} \mathrm{C}, \mathrm{pH} 9.0$ and at $65^{\circ} \mathrm{C}, \mathrm{pH} 7.5$, respectively. They remained active over temperature and $\mathrm{pH}$ ranges of $45-75^{\circ} \mathrm{C}$ and $4.0-10.5$. Their activities retained $65 \%$ and $54 \%$ when incubated at $75^{\circ} \mathrm{C}$ for $10 \mathrm{~min}$ and $98-86.5 \%$ and $95-84.5 \%$ at $\mathrm{pH} 4.0-10.5$ for $15 \mathrm{~h}$ at $37^{\circ} \mathrm{C}$. In conclusion, the $\alpha$-amylase production conditions of D413 have been optimized which can be useful in biotechnological processes such as hydrolysis of starch to glucose.
\end{abstract}

Keywords: Thermostable, $\alpha$-Amylase, Production, Optimization, Geobacillus sp.

\section{INTRODUCTION}

$\alpha$-Amylases (EC 3.2.1.1, 1,4- $\alpha$-D-glucan glucanohydrolases and endoamylases) degrade starch hydrolyzing enzymes by breaking internal $\alpha$-1,4-glucosidic linkages and produce reducing sugars. Starch is an immanent polysaccharide composed of two high-molecular weight components such as amylose and amylopectin. Amylose is a linear chain consisting of units from glucose molecules linked by $\alpha-1,4$ glycosidic bonds. Amylopectin is a branched molecule containing $\alpha-1,6$ linking branch points in addition to $\alpha-1,4$ glycosidic bonds. $\alpha$ amylases are produced abundantly by plants and microorganisms and produce a wide class of industrial enzymes constituting approximately $30 \%$ of the world enzyme market (Van der Maarel et al., 2002).

Of those amylases, microbial $\alpha$-amylases have wide applications in industrial processes such as starch degradation, production of glucose and fructose syrup as well as fruit juices and alcoholic beverages, and also in applications such as detergent, paper and textile industries. Recent studies especially focus on the role of thermostable enzymes in biotechnology and industry, since many industrial enzymatic reactions are performed at elevated temperatures. Therefore, thermostable $\alpha$-amylases take advantage of usage potential in these processes. The microbial $\alpha$-amylases have been described and characterized in some species including Bacillus subtilis, Bacillus amyloliquefaciens, Bacillus licheniformis, Geobacillus thermodenitrificans HRO10 (Ezeji and Bahl, 2006), Geobacillus stearothermophilus ATCC 12016 and Geobacillus stearothermophilus ATCC $12980^{\mathrm{T}}$ (Underkofler, 1976; Suzuki et al., 1984; Ferner-Ortner-Bleckmann et al,. 2009). Some amylase producing strains and their $\mathrm{pH}$ and thermal stabilities are also listed in Table 1. Here we report the characteristic properties of Geobacillus sp D413 $\alpha$-amylase by presenting the thermal and pH activity and stability of its enzyme as well as the optimal culture conditions for enzyme production.

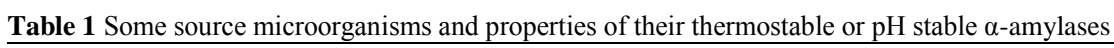

\begin{tabular}{lccccc}
\hline Organism & $\begin{array}{c}\text { Optimum } \\
\text { Temperature }\left({ }^{\circ} \mathbf{C}\right)\end{array}$ & Residual Activity $(\%)$ & Optimum pH & Residual Activity $(\%)$ & Reference \\
\hline Bacillus sp. I-3 & 70 & $50\left(80^{\circ} \mathrm{C}-2.5 \mathrm{~h}\right)$ & 7.0 & 80 & Goyal et al., 2005 \\
\hline Bacillus sp ANT-6 & 80 & $87.7\left(100^{\circ} \mathrm{C}-60 \mathrm{~min}\right)$ & 10.5 & $55(\mathrm{pH}: 1015 \mathrm{~h})$ & Arikan et al., 2003 \\
\hline Bacillus sp PS-7 & 60 & $78\left(50^{\circ} \mathrm{C}-6 \mathrm{~h}\right)$ & 6.5 & $96(\mathrm{pH}: 5.090 \mathrm{~min})$ & Sodhi et al., 2005 \\
\hline L. manihotivorans & 55 & $70\left(50^{\circ} \mathrm{C}-1 \mathrm{~h}\right)$ & 5.5 & $80(\mathrm{pH}: 5.560 \mathrm{~min})$ & Aguilar et al., 2000 \\
\hline Bacillus KSM-K38 & $55-60$ & $20\left(50^{\circ} \mathrm{C}-30 \mathrm{~min}\right)$ & $8.0-9.5$ & $80(\mathrm{pH}: 1130 \mathrm{~min})$ & Hagihara et al., 2001 \\
\hline Bacillus sp. Strain PM1 & 50 & $67\left(50^{\circ} \mathrm{C}-60 \mathrm{~min}\right)$ & 8.0 & $78(\mathrm{pH}: 8.04 \mathrm{~h})$ & Sharma et al., 2014 \\
\hline B. amyloliquefaciens P-001 & 60 & $73\left(50^{\circ} \mathrm{C}-30 \mathrm{~min}\right)$ & 6.5 & - & Deb et al., 2013 \\
\hline $\begin{array}{l}\text { G.thermodenitrificans } \\
\text { HRO10 }\end{array}$ & $75-80$ & $0\left(70^{\circ} \mathrm{C}-30 \mathrm{~min}\right)$ & 5.5 & - & Ezeji and Bahl, 2006 \\
\hline
\end{tabular}




\section{MATERIALS AND METHODS}

\section{Bacterial isolates}

In this study, formerly isolated six thermophilic bacilli and reference strain $G$ stearothermophilus DSMZ $22^{\mathrm{T}}$ were screened for their qualitative and quantitative amylolytic activities. These thermophilic bacilli were formerly isolated from a polyphasic study and known to be amylase-producing strains (Coleri et. al., 2009). Their 16S rRNA gene sequence analyses were also determined from our previous studies and their gene sequences were found in GenBank databases (Cihan et al., 2011 and 2013). The thermophilic isolates used in this study were Geobacillus stearothermophilus A113 (FJ429596), Geobacillus sp. C304 (FJ429574) and Geobacillus sp. D413 (FJ430040), Anoxybacillus caldiproteolyticus D504 (FJ430047), and Anoxybacillus caldiproteolyticus D621 (FJ430050). The reference strain Geobacillus stearothermophilus ATCC $12980^{\mathrm{T}}$ was also used for comparison purposes.

\section{Qualitative and quantitative amylase screening assays}

In qualitative screening assay, a modified method of Dheeran et al. (2010) medium was used for bacterial growth. Amylolytic activity was tested on this modified Dheeran medium containing $0.5 \%$ peptone, $0.5 \%$ yeast extract, $0.5 \%$ $\mathrm{NaCl}, 1.0 \%$ soluble starch and $3.0 \%$ agar $(\mathrm{pH} \mathrm{7.0)}$ after incubation for $24 \mathrm{~h}$ at $55^{\circ} \mathrm{C}$. Then the plates were treated with $0.2 \% \mathrm{I}_{2}$ in $2 \% \mathrm{KI}$ solution and isolates having starch digestion zones around their colonies were determined as amylolytic (Coleri et al., 2009). The halo zone diameters were measured $(\mathrm{cm})$ in order to compare the amylase producing strains, which were produced due to hydrolysis of starch

When determining the quantitative amylolytic activity for the screening assay, a modified Santos and Martins (2003) medium (1.0\% tryptone, $0.5 \%$ yeast extract, $1.0 \%$ soluble starch) was used for enzyme production. The $\mathrm{pH}$ of the medium was adjusted according to the bacteria. The growing cells were suspended in $0.85 \%$ sterile $\mathrm{NaCl}$ and adjusted to $0.2-0.4$ absorbance at $660 \mathrm{~nm}$ and then $500 \mu \mathrm{L}$ from this suspension was inoculated into $5 \mathrm{~mL}$ of enzyme production medium and incubated at $55^{\circ} \mathrm{C}$ by shaking at $150 \mathrm{rpm}$ for $72 \mathrm{~h}$. The cells were collected by centrifugation at $5000 \mathrm{rpm}$ for $15 \mathrm{~min}$ at $4{ }^{\circ} \mathrm{C}$, and the wet weights of the cells were measured. $\alpha$-Amylase production capacities of the isolates were designated based on their total enzyme amount per cell-yield $(\mathrm{U} / \mathrm{g})$ All the experiments were at least triplicate.

\section{Determination of optimal culturing conditions for enzyme production}

In order to optimize the growth $\mathrm{pH}$, temperature and time for achieving the maximum enzyme production, the modified Santos and Martins broth $(1.0 \%$ tryptone, $0.5 \%$ yeast extract, $1.0 \%$ soluble starch,) was used when cultivating the bacteria before measuring the amylase activities. The supernatant was obtained as explained before in the quantitative amylolytic activity assay and was used as an enzyme source for further experiments. In order to compare the $\alpha$-amylase production capacities of the bacteria, total enzyme activity values were divided into biomass of bacterial pellet wet weight $(\mathrm{U} / \mathrm{g})$ throughout all the experiments in this study.

When determining the optimal cultivation conditions for amylase production, either the incubation temperature or the $\mathrm{pH}$ of the modified Santos and Martins medium was changed. For the determination of thermal conditions on enzyme production, bacterial isolates were incubated in this medium by changing the incubation temperature from 50 to $65^{\circ} \mathrm{C}$. On the other hand, the $\mathrm{pH}$ of the medium was adjusted to various $\mathrm{pH}$ values between 3.0 and 10.0 in order to determine the effect of $\mathrm{pH}$ on amylase production. In addition, a time-course was carried out during $96 \mathrm{~h}$ in this broth medium by taking samples at $24 \mathrm{~h}$ intervals. The $\mathrm{pH}$ changes in the medium and also the cell weights were also measured during $96 \mathrm{~h}$ cultivation. All the triplicate experiments were further taken into spectrophotometric amylase assay to measure their enzyme production.

\section{Enzyme assay}

The $\alpha$-amylase activity was determined by spectrophotometric method with measuring the hydrolysis of soluble starch as substrate. The standard reaction mixture was prepared by adding appropriately diluted $0.5 \mathrm{ml}$ enzyme solution to $0.5 \mathrm{ml} 0.2 \mathrm{M}$ sodium phosphate buffer with $0.5 \mathrm{ml} 2 \%$ soluble starch. Reaction was carried out at $65^{\circ} \mathrm{C}$ for $10 \mathrm{~min}$ and it was stopped by boiling $5 \mathrm{~min}$ after addition of $1 \mathrm{ml}$ DNS. When the reaction tube was cooled, the amylase activity was measured spectrophotometrically at $540 \mathrm{~nm}$. One unit of $\alpha$ amylase activity was defined as the amount of enzyme that catalyzed the liberation of reducing sugar equivalent to $1 \mu \mathrm{mol}$ of maltose per min under the assay conditions. The millimolar extinction coefficient of maltose at $540 \mathrm{~nm}, \mathrm{pH} 7.0$ and at $65^{\circ} \mathrm{C}$ were measured as $1.454 \mathrm{M}^{-1} . \mathrm{cm}^{-1}$ and used to calculate the amount of product yielded. The enzyme assays were performed at least three times.
Determination of the effect of different carbon and nitrogen sources on amylase production

Various carbon sources were used for the determination of their effects on amylase production. Therefore, thermophilic isolates were grown in different modified Santos and Martins medium containing $1 \%$ carbon sources such as sucrose, lactose, dextrose, maltose, and soluble starch (Kıran et al., 2005, Pavithra et al., 2014). Of those sources, the concentration of starch was also screened in wider ranges from 0.2 to $1 \%$. Moreover, different nitrogen sources including tryptone, yeast and ammonium chloride, in concentrations from 0.2 to $1 \%$, were studied for their effect of enzyme production. In these assays, the $\mathrm{pH}$ and temperature were adjusted to the determined optimal value according to the bacteria or their enzymes used for both growth conditions and for enzyme assays.

\section{Determination of the effect of temperature and $\mathrm{pH}$ on $\alpha$-amylase activity and stability}

The effect of temperature on enzyme activities was determined on the crude enzymes between $45^{\circ} \mathrm{C}$ to $75^{\circ} \mathrm{C}$ with $5^{\circ} \mathrm{C}$ intervals. For stability tests, enzymes were heated for $10 \mathrm{~min}$ at different temperatures, then quickly chilled on ice and assayed for the remaining activity at its optimal $\mathrm{pH}$ and temperature. The effect of $\mathrm{pH}$ on the enzyme activity was determined using $0.02 \mathrm{M}$ sodium-citrate $(\mathrm{pH}$ 4.0, 4.5, 5, 5.5, 6.0), $0.1 \mathrm{M}$ sodium phosphate $(\mathrm{pH} 6.5,7,7.5,8.0)$ and $50 \mathrm{mM}$ glycine- $\mathrm{NaOH}(\mathrm{pH} 8.5,9.0,9.5,10.0,10.5)$ buffers at $65^{\circ} \mathrm{C}$, all instead of $0,2 \mathrm{M}$ potassium phosphate buffer in the standard assay mixture. The effect of $\mathrm{pH}$ on $\alpha$ amylase stability was examined by incubating the enzymes in the same buffers $(\mathrm{pH} 4.0-10.5)$ at $37^{\circ} \mathrm{C}$ for $15 \mathrm{~h}$ as reported in the activity test. The activity of the not-heated and not $\mathrm{pH}$-treated enzyme was expressed as $100 \%$.

\section{RESULTS}

\section{Screening results and optimization of culture conditions}

In this study, six thermophilic bacilli and an amylase producing reference strain were screened for their $\alpha$-amylase activity both qualitatively and quantitatively. The zone diameters and the specific $\alpha$-amylase activity results obtained from screening assays were listed in Table 2. According to these results, the highest $\alpha$ amylase producing strain was found as Geobacillus sp. D413 with a zone diameter of $0.5 \mathrm{~cm}$ and with a specific enzyme activity of $15.84 \mathrm{U} / \mathrm{g}$, whereas these values were determined as $15.79 \mathrm{U} / \mathrm{g}$ and $0.3 \mathrm{~cm}$ for the reference strain $G$. stearothermophilus ATCC $12980^{\mathrm{T}}$. Consequently, as the the largest zone diameter after $24 \mathrm{~h}$ and the maximum specific activity after $72 \mathrm{~h}$ were observed in Geobacillus sp. D413, D413 isolate and the reference strain were selected for further optimization analyses.

Table 2 The zone diameters and specific enzyme activities of bacteria obtained from screening assays

\begin{tabular}{lcc}
\hline Bacteria & $\begin{array}{c}\text { Zone } \\
\text { diameters } \\
(\mathbf{c m})\end{array}$ & $\begin{array}{c}\text { Enzyme } \\
\text { activity/biomass } \\
(\mathbf{U} / \mathbf{g})\end{array}$ \\
\hline Geobacillus sp. D413 & 0.5 & 15.84 \\
\hline $\begin{array}{l}\text { Geobacillus stearothermophilus } \\
\text { ATCC } 12980^{\mathrm{T}}\end{array}$ & 0.3 & 15.79 \\
\hline $\begin{array}{l}\text { Geobacillus } \text { sp. C304 } \\
\text { Geobacillus stearothermophilus }\end{array}$ & 0.4 & 13.33 \\
\hline $\begin{array}{l}\text { Anoxybacillus caldiproteolyticus } \\
\text { D504 }\end{array}$ & 0.2 & 9.32 \\
\hline $\begin{array}{l}\text { Anoxybacillus caldiproteolyticus } \\
\text { D621 }\end{array}$ & 0.1 & 8.46 \\
\hline $\begin{array}{l}\text { Anoxybacillus caldiproteolyticus } \\
\text { D623 }\end{array}$ & 0.2 & 7.76 \\
\hline
\end{tabular}

When the culture conditions were adjusted between the temperatures from 55 $65^{\circ} \mathrm{C}$ (Fig. 1a) and $\mathrm{pH}$ values of 3.0-10.0 (Fig. 1b), the optimal incubation temperature for the maximum amylase production was determined as $55^{\circ} \mathrm{C}$ for both of the bacteria, but they differed in optimal bacterial growth $\mathrm{pH}$ for the highest amylase production. $\mathrm{pH} 7.0(12,9 \mathrm{U} / \mathrm{g})$ and $\mathrm{pH} 8.0(11,73 \mathrm{U} / \mathrm{g})$ were found as optimal values for the isolate D413 and strain ATCC $12980^{\mathrm{T}}$, respectively. If the culture medium was adjusted to a $\mathrm{pH}$ value of 4.0 , it seems that Geobacillus sp. D413 could not grow in the medium. This case was shown at previous studies. (Dheeran et al., 2010; Suman and Ramesh, 2010) Furthermore, enzyme production was diminished, when the temperature was below and above $55^{\circ} \mathrm{C}$. 

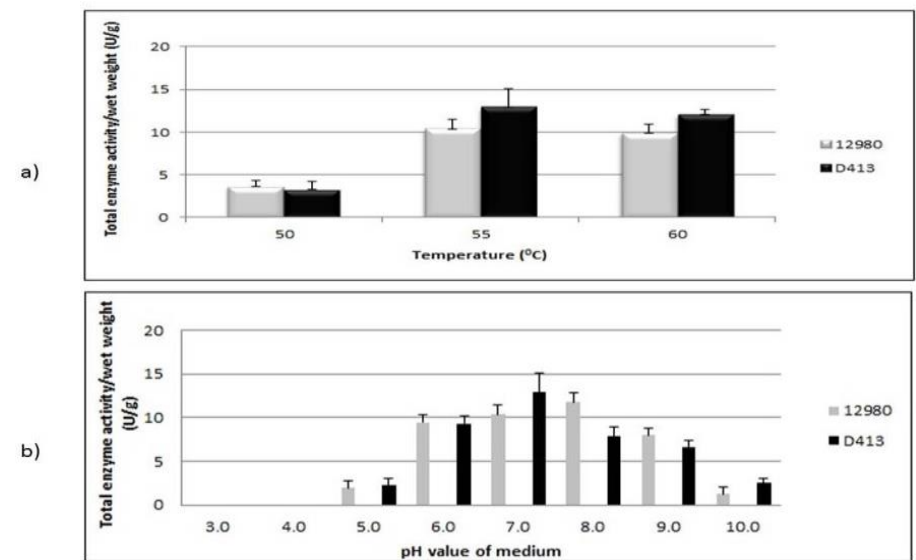

Figure 1 Enzyme production of G.stearothermophilus ATCC $12980^{\mathrm{T}}$ and Geobacillus sp. D413 in medium containing $1 \%$ starch, $0.5 \%$ yeast extract and 1 $\%$ tryptone at different a) temperatures, and $\mathrm{b}$ ) $\mathrm{pH}$.

In addition, Geobacillus sp. D413 isolate and standard strain were incubated at $55^{\circ} \mathrm{C}$ and at $150 \mathrm{rpm}(\mathrm{pH} 7.0$ or 8.0 ) for $96 \mathrm{~h}$ in broth medium containing $1 \%$ starch (Fig. 2). The experiments on growth patterns and time-course of $\alpha$-amylase production by D413 and ATCC $12980^{\mathrm{T}}$ revealed that the maximum extracellular enzyme activity was observed at the time of $72 \mathrm{~h}$, for both D413(15.84 U/g) and ATCC $12980^{\mathrm{T}}(15.79 \mathrm{U} / \mathrm{g})$. Moreover, time-course revealed that the highest $\alpha$ amylase production was achieved when the $\mathrm{pH}$ of the medium were diminished up to 5.0 on $72 \mathrm{~h}$ from their optimal $\mathrm{pH}$ values $(7.0$ or 8.0$)$ for both of the strains. Therefore, in order to reach to the highest amylase production, both D413 and ATCC $12980^{\mathrm{T}}$ were incubated at $55^{\circ} \mathrm{C}$ and $\mathrm{pH} 7.0$ or 8.0 by shaking at $150 \mathrm{rpm}$, in rest of the studies, respectively.

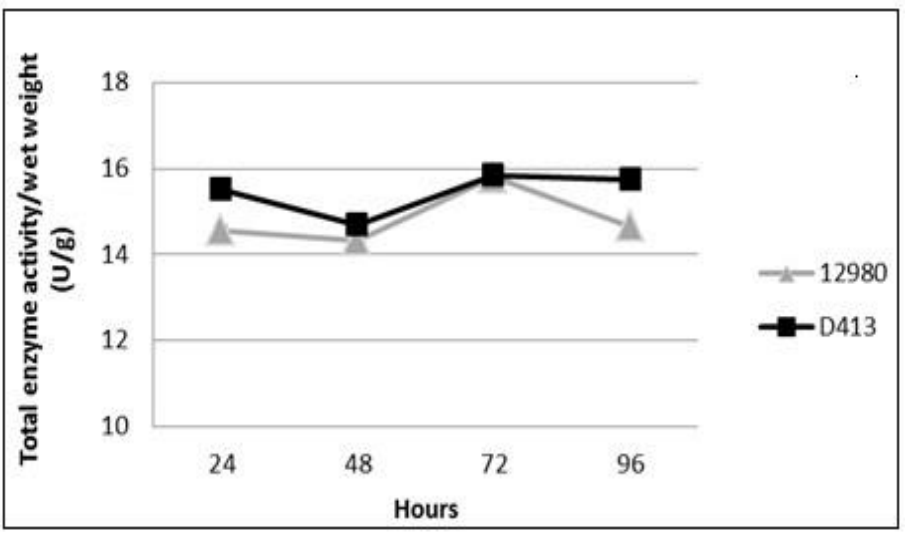

Figure 2 Time course of G.stearothermophilus ATCC $12980^{\mathrm{T}}(\Delta)$ and Geobacillus sp. D413 ( $\square$ ) during $96 \mathrm{~h}$ in medium containing $1 \%$ starch, $0.5 \%$ yeast extract and $1 \%$ tryptone at $55^{\circ} \mathrm{C}$.

\section{Effects of different carbon sources on enzyme activities}

Among the different carbon sources such as starch, maltose, sucrose, dextrose and lactose, used in a concentration of $1 \%$, the maximum enzyme production was observed with maltose for both of the bacteria. The specific activity values of 17.85 and $24.85 \mathrm{U} / \mathrm{g}$ were found with the addition of maltose for ATCC 12980 and D413 amylases, respectively. These results are presented in Fig. 3.

As starch is an important substrate for fermentation experiments for amylases, and as it was found to be the second carbon choice for amylase production by isolate D413 $(15,38 \mathrm{U} / \mathrm{g})$ and strain ATCC $12980^{\mathrm{T}}(13,6 \mathrm{U} / \mathrm{g})$, the effects of different starch concentrations were also experimented as presented in Fig. 4. The optimum concentration for soluble starch was determined as $10 \mathrm{~g} / \mathrm{L}$ and below this value a speed decline was observed especially in the case of ATCC 12980 amylase production.

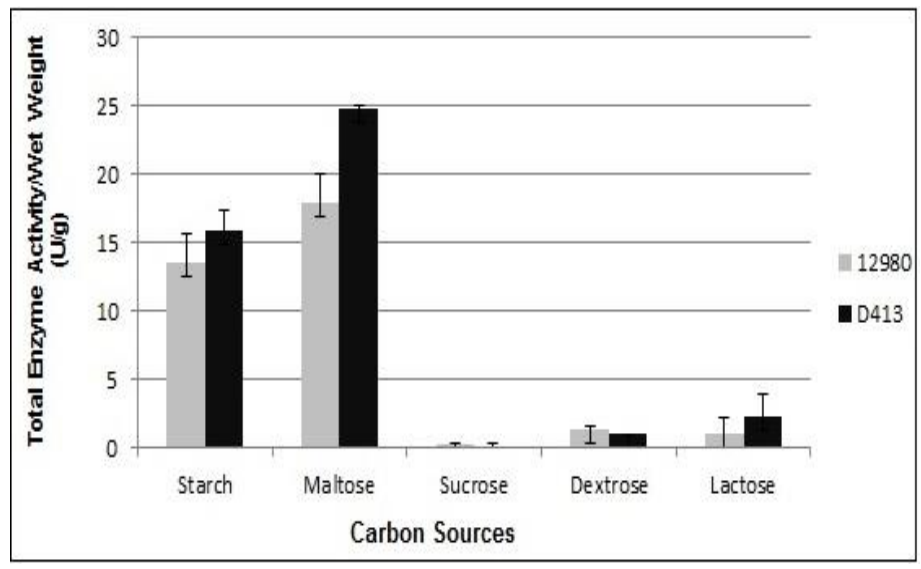

Figure 3 Effects of different carbon sources on amylase production by G.stearothermophilus ATCC $12980^{\mathrm{T}}$ and Geobacillus sp. D413 at $55^{\circ} \mathrm{C}$.

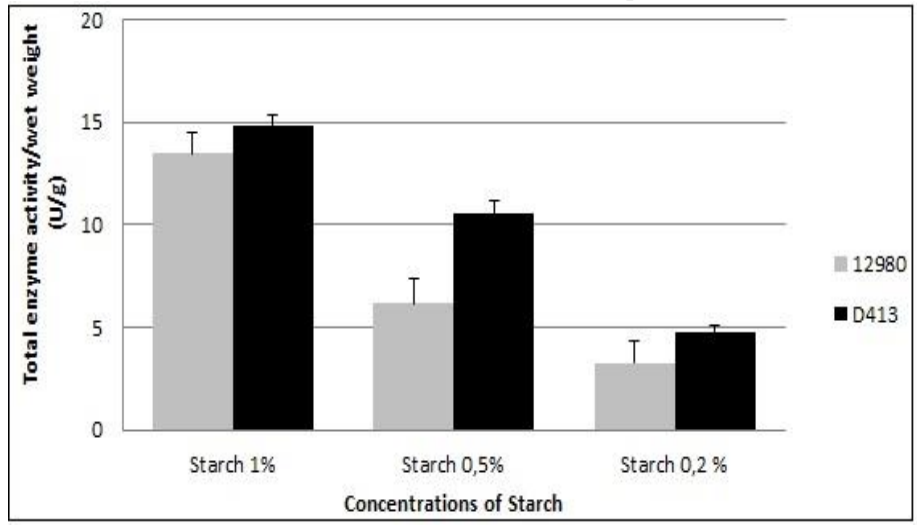

Figure 4 Effects of different concentrations of starch on amylase production by G.stearothermophilus ATCC $12980^{\mathrm{T}}$ and Geobacillus sp. D413 at $55^{\circ} \mathrm{C}$.

\section{Effects of different nitrogen sources on amylase activities}

When determining the effects of different nitrogen sources on amylase production, various concentrations of inorganic and organic compounds were added to the amylase production medium (Fig. 5). If only the inorganic nitrogen source ammonium chloride was used, the bacterial growth and enzyme production was inhibited. While the amylase production of strain D413 was diminished to $1.56 \mathrm{U} / \mathrm{g}$, this value was found to be $0.59 \mathrm{U} / \mathrm{g}$ for strain ATCC $12980^{\mathrm{T}}$. In the other case, if the ammonium chloride in addition to tryptone or yeast extract were used with conjunction as double nitrogen sources, bacterial growth continued, but the enzyme production diminished for both of the bacteria $\leq 1 \mathrm{U} / \mathrm{g}$ ). Therefore, it can be concluded that ammonium chloride had inhibitory effects for these $\alpha$-amylase.

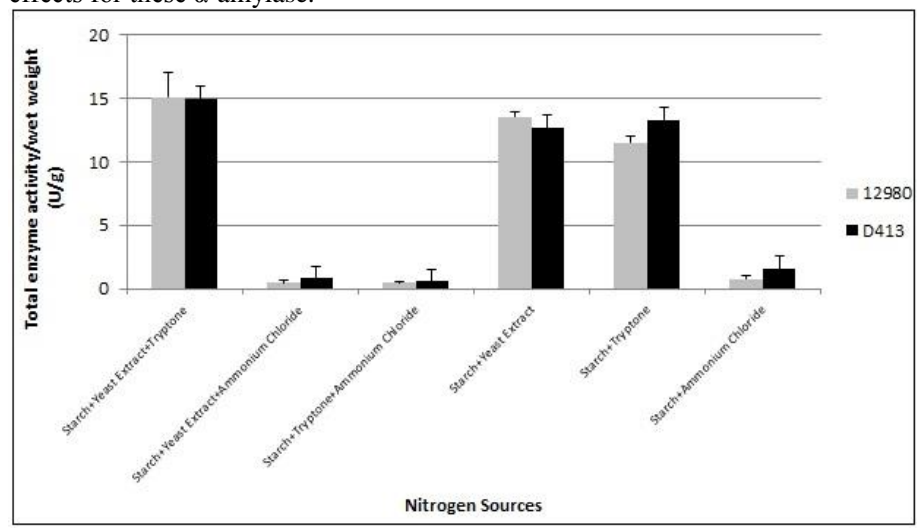

Figure 5 Effects of different nitrogen sources on amylase production by G.stearothermophilus ATCC $12980^{\mathrm{T}}$ and Geobacillus sp. D413 at $55^{\circ} \mathrm{C}$.

Among the organic nitrogen sources, neither_solely the yeast extract nor the tryptone addition increased the amylase activity for both of the enzymes. However, maximum enzyme production was observed at medium supplemented with both $0.5 \%$ yeast extract and $1 \%$ tryptone together as shown in Fig. 6 . The amylase activities in the presence of yeast extract $(0.5 \%)$ and tryptone (1\%) were found to be $15.38 \mathrm{U} / \mathrm{g}$ and $13.6 \mathrm{U} / \mathrm{g}$ for D413 and ATCC 12980, respectively. If the concentrations of tryptone and yeast extract fell down in the medium, enzyme production of the reference strain showed a sharper decrease than the isolate D413. In a previous study of Hamilton et al. (1999) yeast extract turned out to be 
the best nitrogen source for maximum amylase activity. However, Saxena et al. (2007) found the maximum amylase activity at medium supplemented with $0.5 \%$ peptone and $0.3 \%$ yeast extract for Bacillus sp. PN5. Therefore, it seems that the effects of various nitrogen sources also vary with the source organisms as in the case of carbon sources. As a consequence, the inorganic nitrogen source of $0.5 \%$ ammonium chloride inhibit both the bacterial growth and amylase production; however, the organic sources like $0.5 \%$ tryptone and $1 \%$ yeast extract supported the growth and enzyme secretion for both strain ATCC 12980 and isolate D413. The effects of different carbon and nitrogen sources on the amylase production of these bacteria were also listed totally in Table 3.

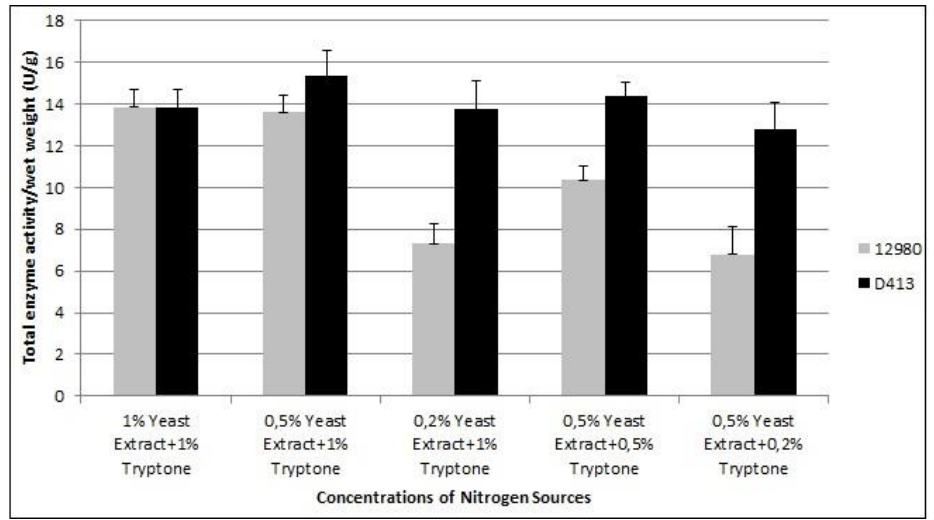

Figure 6 Effects of different concentrations of yeast extract and tryptone on amylase production by G.stearothermophilus ATCC $12980^{\mathrm{T}}$ and Geobacillus sp. $\mathrm{D} 413$ at $55^{\circ} \mathrm{C}$

Table 3 Effects of different carbon and nitrogen sources on amylase production

\begin{tabular}{|c|c|c|c|c|}
\hline \multirow{2}{*}{$\begin{array}{l}\text { Media } \\
\text { (Content \%) }\end{array}$} & \multicolumn{2}{|c|}{ G. stearothermophilus ATCC 12980} & \multicolumn{2}{|c|}{ Geobacillus sp. D413 } \\
\hline & $\begin{array}{c}\text { Enzyme activity } \\
(\mathrm{U} / \mathrm{ml})\end{array}$ & $\begin{array}{c}\text { Enzyme activity/biomass } \\
(\mathbf{U} / \mathrm{g})\end{array}$ & $\begin{array}{l}\text { Enzyme activity } \\
(\mathbf{U} / \mathbf{m l})\end{array}$ & $\begin{array}{c}\text { Enzyme activity/biomass } \\
\text { (U/g) }\end{array}$ \\
\hline Starch + Yeast Extract + Tryptone $(1 ; 0.5 ; 1)$ & $0.95 \pm 0.16$ & $13.6 \pm 1.48$ & $1.23 \pm 0.05$ & $15.38 \pm 1.59$ \\
\hline Starch + Yeast Extract + Tryptone $(0.5 ; 0.5 ; 1.0)$ & $0.55 \pm 0.10$ & $6.19 \pm 1.21$ & $0.73 \pm 0.04$ & $10.53 \pm 0.66$ \\
\hline Starch + Yeast Extract + Tryptone $(0,2 ; 0.5 ; 1.0)$ & $0.16 \pm 0.04$ & $3.29 \pm 1.03$ & $0.38 \pm 0.02$ & $4.79 \pm 0.29$ \\
\hline Starch + Yeast Extract + Tryptone $(1.0 ; 0.2 ; 1.0)$ & $0.58 \pm 0.07$ & $7.31 \pm 0.92$ & $1.37 \pm 0.13$ & $13.73 \pm 1.36$ \\
\hline $\begin{array}{l}\text { Starch + Yeast Extract + Tryptone }(1.0 ; 0.5 ; \\
0.5)\end{array}$ & $0.73 \pm 0.05$ & $10.36 \pm 0.64$ & $1.44 \pm 0.21$ & $14.38 \pm 2.10$ \\
\hline $\begin{array}{l}\text { Starch + Yeast Extract + Tryptone }(1.0 ; 0.5 ; \\
0.2)\end{array}$ & $0.54 \pm 0.10$ & $6.79 \pm 1.30$ & $1.28 \pm 0.09$ & $12.77 \pm 0.90$ \\
\hline Starch + Yeast Extract $(1.0 ; 0.5)$ & $0.79 \pm 0.02$ & $13.51 \pm 0.47$ & $1.01 \pm 0.10$ & $12.63 \pm 1.67$ \\
\hline Starch + Tryptone $+\mathrm{NH}_{4} \mathrm{Cl}(1.0 ; 1.0 ; 0.5)$ & $0.03 \pm 0.008$ & $0.44 \pm 0.07$ & $0.06 \pm 0.01$ & $0.55 \pm 0.10$ \\
\hline Starch $+\mathrm{NH}_{4} \mathrm{Cl}(1.0 ; 0.5)$ & $0.02 \pm 0.001$ & $0.59 \pm 0.21$ & $0.05 \pm 0.01$ & $1.56 \pm 0.33$ \\
\hline $\begin{array}{l}\text { Sucrose + Yeast Extract + Tryptone }(1.0 ; \\
0.5 ; 1.0)\end{array}$ & $0.01 \pm 0.008$ & $0.21 \pm 0.018$ & $0.01 \pm 0.007$ & $0.14 \pm 0.11$ \\
\hline $\begin{array}{l}\text { Dextrose + Yeast Extract + Tryptone }(1.0 ; 0.5 ; \\
1.0)\end{array}$ & $0.08 \pm 0.009$ & $1.35 \pm 0.19$ & $0.09 \pm 0.005$ & $0.96 \pm 0.05$ \\
\hline $\begin{array}{l}\text { Lactose + Yeast Extract + Tryptone }(1.0 ; 0.5 ; \\
1.0)\end{array}$ & $0.06 \pm 0.08$ & $1.05 \pm 0.16$ & $0.21 \pm 0.10$ & $2.30 \pm 1.56$ \\
\hline $\begin{array}{l}\text { Maltose + Yeast Extract + Tryptone }(1.0 ; 0.5 ; \\
1.0)\end{array}$ & $0.89 \pm 0.06$ & $17.85 \pm 1.25$ & $1.49 \pm 0.20$ & $24.85 \pm 3.29$ \\
\hline
\end{tabular}

Effect of temperature and pH on enzyme activities and stabilities

Some distinctions were determined in both of these enzymes revealed by the temperature and $\mathrm{pH}$ activity and stabilities. The strain D413 extracellular $\alpha$ amylase had temperature optima of $65^{\circ} \mathrm{C}$ and $\mathrm{pH}$ optima of 9.0. These values were found to be $65^{\circ} \mathrm{C}$ and $\mathrm{pH} 7.5$ for strain ATCC 12980, respectively (Fig. 7a, b). After this temperature, especially for Geobacillus sp. D413, $\alpha$-amylase activity was decreased. Both of these enzymes were very stable between temperature ranges from $45^{\circ} \mathrm{C}$ to $75^{\circ} \mathrm{C}$ and $\mathrm{pH}$ ranges from 4.0 to 10.5 (Fig. 8a, b). It is noteworthy that although the optimal growth $\mathrm{pH}$ (8.0) of ATCC 12980 was higher than $\mathrm{D} 413(\mathrm{pH}$ 7.0) enzyme, the optimal amylase activity was observed in a value lower than D413 amylase. Notably, when the extracellular $\mathrm{D} 413 \alpha$-amylase was incubated at $75^{\circ} \mathrm{C}$ for $10 \mathrm{~min}$, it retained $65 \%$ of its activity. This value was determined to be $54 \%$ for the reference strain. In addition, when D413 amylase was treated with buffers having pH:4.0 and 10.5 at $37^{\circ} \mathrm{C}$ for $15 \mathrm{~h}$, it gained $98 \%$ and $86.5 \%$ of its activity, respectively. These were observed as $\mathrm{pH} 95 \%$ and $84.5 \%$ for ATCC $12980^{\mathrm{T}}$ amylase.

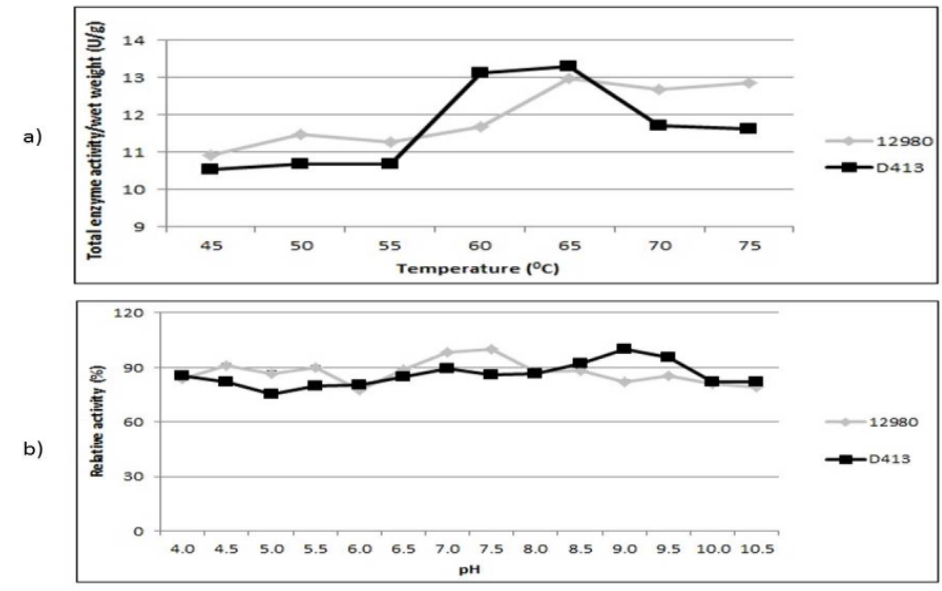

Figure 7 Effects of G.stearothermophilus ATCC $12980^{\mathrm{T}}(\diamond)$ and Geobacillus sp. D413 ( $\square$ ) amylase activities under different a) temperatures at $\mathrm{pH} 7.0$ and b) $\mathrm{pH}$ values at $65^{\circ} \mathrm{C}$. 

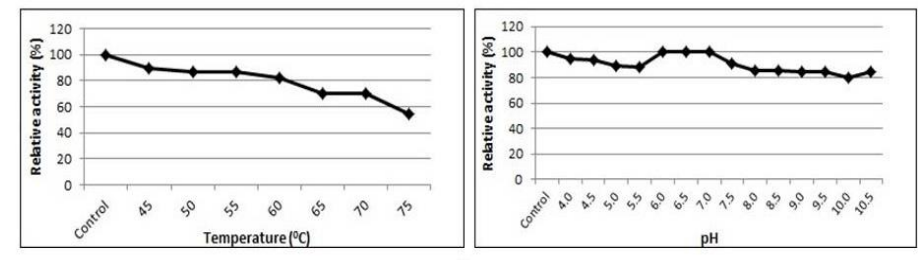

a
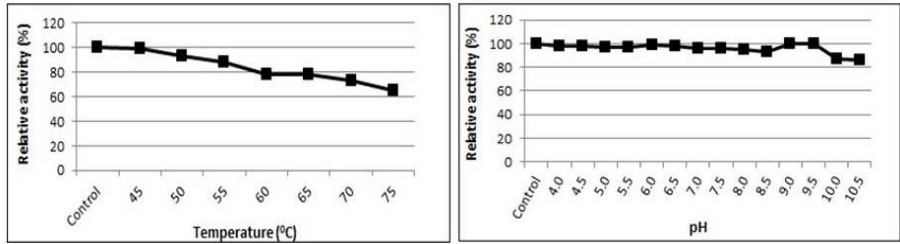

Figure 8 Temprerature and $\mathrm{pH}$ stabilities of amylases from a) $G$ stearothermophilus ATCC $12980^{\mathrm{T}}(\diamond)$ and b) Geobacillus sp. D413 ( $\square$ )

\section{DISCUSSION}

Amylases are among the most important enzymes and are of great significance in biotechnological processes. Particularly thermostable alpha amylases are used in many industrial processes at high temperature. In the present paper, we report the characterization of novel thermostable amylase produced by thermophilic strain Geobacillus sp. D413, which efficiently hydrolyzes the starch biomass. As a result of scanning performed amylase activity; Geobacillus sp. D413 has been selected as the best enzyme producing isolate. Enzyme production of Geobacillus sp. D413 has been optimized and used in G. stearothermophilus ATCC 12980.

Culture conditions (medium $\mathrm{pH}$, incubation temperature, incubation time, and carbon and nitrogen sources) were determined for maximum enzyme production For the maximum enzyme production optimal temperature and $\mathrm{pH}$ was found to be $55^{\circ} \mathrm{C}$ and $\mathrm{pH}: 7.0$, respectively for our isolate. In general, most of the thermophilic members from Bacillaceae family were reported to produce maximum enzyme production at temperatures ranging from $35^{\circ} \mathrm{C}$ to $60^{\circ} \mathrm{C}$ (Kiran et al., 2005; Dheeran et al., 2010; Suman and Ramesh, 2010). On the other hand, the enzyme production was found to be inhibited $(\leq 1.0 \mathrm{U} / \mathrm{g})$ when sucrose, lactose and glucose were used as carbon sources. The previous studies have revealed that especially production of carbohydrate degrading enzymes in most species of the genus Bacillus is exposed to catabolic repression being readily metabolized in the presence of substrates such as glucose (Lin et al., 1998). As starch is an important substrate for fermentation experiments for amylases and as it was found to be the second carbon choice for amylase production by isolate D413 (15.38 U/g) and strain ATCC $12980^{\mathrm{T}}(13.6 \mathrm{U} / \mathrm{g})$. Also, the enzyme activity was found to be associated with the starch concentration. Therefore, a direct proportion was observed between the starch concentration in the medium and the amylase production for both of the bacteria. Similar to this finding, Suman and Ramesh (2010) demonstrated the optimum concentration of soluble starch to be $20 \mathrm{~g} / \mathrm{L}$ for Bacillus strain KCPSS-12ss amylase.

The optimal temperature and $\mathrm{pH}$ for $\alpha$-amylase activities were within the ranges (30 to $105^{\circ} \mathrm{C}$ ) of the reported $\alpha$-amylases from endospore-forming bacilli (Teodoro and Martins, 2000; Ezeji and Bahl, 2006; Asgher et al., 2007; Saxena et al., 2007; Arikan, 2008; Asoodeh et al., 2010). Among the previous studies, Ezeji and Bahl (2006) reported that G. thermodenitrificans HRO10 amylase retained $53.4 \%$ of its original activity after incubation without substrate at $70^{\circ} \mathrm{C}$ for $10 \mathrm{~min}$. These results are in agreement with the reports of Ezeji and Bahl (2006) and Teodoro and Martins (2000); and in those studies optimum temperature was diminished beyond of $55^{\circ} \mathrm{C}$ and was inactivated at $95^{\circ} \mathrm{C}$ for ten min. Also Oziengbe and Onilude (2012) have determined that deterioration took place in the stability of $B$. licheniformis amylase after temperature above $70^{\circ} \mathrm{C}$. Similar results were reported in the study of Asgher et al., 2007. In that study, they found that the a-amylase of B. subtilis JS-2004 strain lost only its $\% 6$ of its original activity after incubation for $24 \mathrm{~h}$ at its optimum $\mathrm{pH}$. But in the study of Ezeji and Bahl (2006), G. thermodenitrificans HRO10 $\alpha$-amylase showed maximum activity in an acidic $\mathrm{pH}$ such as 5.5. Therefore, when compared with the ATCC 1280 and other source microorganisms, the extracellular $\alpha$-amylase of D413 differed from other bacilli enzymes by means of its temperature and $\mathrm{pH}$ optima values, by its high thermostability at its optimal temperature and also by its broad $\mathrm{pH}$ stabilities. Especially the $\alpha$-amylase of D413 can be more active and stable on an alkaline $\mathrm{pH}$ such as 9.0, and differed from ATCC 12980 enzymes having optimum $\mathrm{pH} 7.0$ at neutral conditions.

\section{CONCLUSION}

Microbial $\alpha$-amylases are in use in industrial processes occupying approximately $30 \%$ of the world enzyme market. As in these processes the desired parameters are thermal and $\mathrm{pH}$ stability, the $\alpha$-amylase production, activity and stability conditions were determined for optimal amylase production from Geobacillus $\mathrm{sp}$ D413 by comparing the reference strain G. stearothermophilus ATCC 12980 in this study. As a result of the optimization studies, it was observed that when D413 enzyme was incubated at $55^{\circ} \mathrm{C}$ and $\mathrm{pH} 7.0$ in media containing $1 \%$ soluble starch, $0.5 \%$ yeast extract and $1 \%$ tryptone, it showed maximum activity at $\mathrm{pH}$ 9.0 and at $65^{\circ} \mathrm{C}$. D413 $\alpha$-amylase enzyme was also found to be stable at $75^{\circ} \mathrm{C}$ and pH 10.5. Geobacillus sp. D413 $\alpha$-amylase possesses high conformational stability at elevated temperatures, has an optimal $\mathrm{pH}$ at alkaline environments and shows activity in broad $\mathrm{pH}$ ranges; all these characteristic properties of the extracellular Geobacillus sp. D413 $\alpha$-amylase are required parameters in enzymes desired for biotechnologically important industrial applications. Thus, when its $\mathrm{pH}$ optima and conformational stability are considered, the D413 $\alpha$-amylase may prove to have a potential in biotechnological processes such as hydrolysis of starch to glucose.

\section{REFERENCES}

Aguilar, G., Morlon, J., Guyot, B., Trejo-Aguilar, P. (2000). Purification and characterization of an extracellular a-amylase produced by Lactobacillus manihotivorans LMG 18010T, an amylolytic lactic acid bacterium. Enzyme Microb. Technol., 27:406 - 413. http://dx.doi.org/10.1016/s0141-0229(00)00230-

Arikan, B. (2008). Highly thermostable, thermophilic, alkaline, SDS and chelator resistant amylase from a thermophilic Bacillus sp. isolate A3-15. Bioresource Technology, 99:3071-3076. http://dx.doi.org/10.1016/j.biortech.2007.06.019 Arikan, B., Ünaldı, N., Coral, G., Colak, O., Aygan, A. and Gülnaz, O. (2003). Enzymatic properties of a novel thermostable, thermophilic, alkaline and chelator resistant amylase from an alkaliphilic Bacillus sp. isolate ANT-6. Process Biochemistry, 38:1397-1403. http://dx.doi.org/10.1016/s0032-9592(03)00037-2 Asgher, M., Asad, M.J., Rahman, S.U., Legge, R.L. (2007). A thermostable aamylase from a moderately thermophilic Bacillus subtilis strain for starch processing. Journal of Food Engineering, , 79: 950955. http://dx.doi.org/10.1016/j.jfoodeng.2005.12.053

Asoodeh, A., Chamani, J., Lagzian, M. (2010). A novel thermostable, acidophilic alpha-amylase from a new thermophilic "Bacillus sp. Ferdowsicous" isolated from Ferdows hot mineral spring in Iran: Purification and biochemical characterization. International Journal of Biological Macromolecules, 46:289 297. http://dx.doi.org/10.1016/j.ijbiomac.2010.01.013

Cihan, A.C., Ozcan, B., Tekin, N., Cokmus, C. (2011). Phylogenetic diversity of isolates belonging to genera Geobacillus and Aeribacillus isolated from different geothermal regions of Turkey. World J. Microbiol. Biotechnol., 27: 2683-2696. http://dx.doi.org/10.1007/s11274-011-0742-2

Cihan, A. C. (2013). Taxonomic Classification of Anoxybacillus Isolates from Geothermal Regions in Turkey by $16 \mathrm{~S}$ rRNA Gene Sequences and ARDRA, ITSPCR, Rep-PCR Analyses. Pol. J. Microbiol, 62:149-163 http://www.pjmonline.org/pjm-2013-vol-62/

Coleri, A., Cokmus, C., Ozcan, B., Akkoc, N., Akcelik, M. (2009). Isolations of $\alpha$-glucosidase-producing thermophilic bacilli from hot springs of Turkey. Microbiology, 78:56-66. http://dx.doi.org/10.1134/s0026261709010081

Deb, P., Talukdar, S.A., Mohsina, K., Sarker, P.K., Sayem, S.M.A. (2013) Production and partial characterization of extracellular amylase enzyme from Bacillus amyloliquefaciens P-001. Springer Plus, 2:154 http://dx.doi.org/10.1186/2193-1801-2-154

Dheeran, P., Kumar, S., Jaiswal, Y.K., Adhikari, D.K. (2010). Characterization of hyperthermostable $\alpha$-amylase from Geobacillus sp. IIPTN. Appl. Microbiol. Biotechnol., 86:1857-1866. http://dx.doi.org/10.1007/s00253-009-2430-9

Ezeji, T.C., and Bahl, H. (2006). Purification, characterization, and synergistic action of phytate-resistant alpha-amylase and alpha-glucosidase from Geobacillus thermodenitrificans HRO10. Journal of Biotechnology, 125: 27-38 http://dx.doi.org/10.1016/j.jbiotec.2006.02.006

Ferner-Ortner-Bleckmann, J., Huber-Gries, C., Pavkov, T., Keller, W., Mader C., Ilk, N., Sleytr, U.B., Egelseer, E.M. (2009). The high-molecular-mass amylase (HMMA) of Geobacillus stearothermophilus ATCC 12980 interacts with the cell wall components by virtue of three specific binding regions. Mol Microbiol., $\quad$ 72(6):1448-1461. http://dx.doi.org/10.1111/j.1365 2958.2009.06734.X

Goyal, N., Gupta, J.K., Soni, S.K. (2005). A novel raw starch digesting thermostable a-amylase from Bacillus sp. I-3 and its use in the direct hydrolysis of raw potato starch. Enzyme Microb. Technol., 37:723-734. http://dx.doi.org/10.1016/j.enzmictec.2005.04.017

Hagihara, H., Igarashi, K., Hayashi, Y., Endo, K., Ikawa-Itayama, K., Ozaki, K., Kawai, S., Ito, S. 2001. Novel alpha-amylase that is highly resistant to chelating reagents and chemical oxidants from the alkaliphilic Bacillus isolate KSM-K38. $\begin{array}{lll}\text { Appl. } & \text { Environ. } & \text { Microbiol., }\end{array}$ 1750. http://dx.doi.org/10.1128/aem.67.4.1744-1750.2001

Hamilton, L.M., Kelly, C.T., Fogarty, W.M. (1999). Purification and properties of the raw starch degrading $\alpha$-amylase of Bacillus sp. IMD434. Biotechnol. Lett. 2:111-115. http://dx.doi.org/10.1016/s0032-9592(99)00028-x 
Kiran, O., Comlekcioglu, U., Arikan, B. (2005). Effects of Carbon Sources and Various Chemicals on the Production of a Novel Amylase from a Thermophilic Bacillus sp. K-12. Turk. J. Biol., 29:99-103 (C) TÜBİTAK.

Lin, L.L., Chyau, C.C., Hsu ,W.H. (1998). Production and properties of a rawstarch-degrading amylase from thermophilic and alkaliphilic Bacillus sp. TS-23. Biotechnol. Appl. Biochem., 28:61-68.

Oziengbe, E.O., Onilude, A.A. (2012). Production of a thermostable $\alpha$-amylase and its assay using Bacillus licheniformis isolated from excavated land sites in Ibadan, Nigeria. Bayero Journal of Pure and Applied Sciences, 5(1):132 - 138 http://dx.doi.org/10.4314/bajopas.v5i1.24

Pavithra, S., Ramesh, R., Aarthy, M., Ayyadurai, N., Gowthaman M.K., Kamini N. R. (2014). Starchy substrates for production and characterization of Bacillus subtilis amylase and its efficacy in detergent and breadmaking formulations. Starch/Stärke, 66:976-984. http://dx.doi.org/10.1002/star.201400066

Santos, E.O., Martins, M.L.L. (2003). Effect of the medium composition on formation of amylase by Bacillus sp. Brazilian Archieves Biology and Technology, 46(1):129-134. http://dx.doi.org/10.1590/s1516 89132003000100018

Saxena, R.K., Dutt, K., Agarwal, L., Nayyar, P. (2007). A highly thermostable and alkaline amylase from a Bacillus sp. PN5. Bioresource Technology, 98:260 265 http://dx.doi.org/10.1016/j.biortech.2006.01.016

Sharma, K., Bhutty, S., Khurana, S.M.P., Kohli, U.K. (2014). Isolation, Identification and Optimization of Culture Conditions of Bacillus sp. Strain PM1 for Alkalo-thermostable Amylase Production. British Microbiology Research Journal, 4(4):369-380. http://dx.doi.org/10.9734/bmrj/2014/6873

Sodhi, H.K, Sharma, K., Gupta, J.K., Soni, S.K. (2005). Production of a thermostable a-amylase from Bacillus sp. PS-7 by solid- state fermentation and its synergistic use in the hydrolysis of malt starch for alcohol production. Process Biochem., 40:525-534. http://dx.doi.org/10.1016/j.procbio.2003.10.008

Suman, S., Ramesh, K. (2010). Production of a thermostable extracellular amylase from thermophilic Bacillus species. J. Pharm. Sci. \& Res., 2(2):149-154. Suzuki, Y., Shinji, M., Eto, N. (1984). Assignment of a $\rho$-nitrophenyl- $\alpha$-Dglucopyranosidase of Bacillus stearothermophilus ATCC 12016 to a novel exo$\alpha$-1,4-glucosidase active for oligomaltosaccharides and $\alpha$-glucans. Biochimica et Biophysica Acta, 787:281-289. http://dx.doi.org/10.1016/0167-4838(84)903212

Teodoro, C.E.S., Martins, M.L.L. (2000). Culture conditions for the production of thermostable amylase by Bacillus sp. Brazilian Journal of Microbiology, 31:298-302. http://dx.doi.org/10.1590/s1517-83822000000400011

Underkofler, L. (1976). Microbial enzymes. In: Miller, B., Litsky, W. (Eds.)." Industrial Microbiology. New York: McGraw-Hill http://dx.doi.org/10.1177/002218567601800212

Van der Maarel, M.J.E.C., Van der Veen, B., Uitdehaag, J.C.M., Leemhuis H., Dijkhuizen L. (2002). Properties and applications of starch-converting enzymes of the a-amylase family. J Biotechnol., 94:137155. http://dx.doi.org/10.1016/s0168-1656(01)00407-2 